\title{
Comparative Economics of Pulses and Wheat Production in Uttar Pradesh
}

\author{
Vikas Kumar*, Dinesh Chand Meena and Khem Chand
}

ICAR- National Institute of Agricultural Economics and Policy Research, Pusa, New Delhi, India

*Corresponding author: 4vikaskumar@gmail.com

Received: $15-08-2020$

Revised: 28-11-2020

Accepted: 04-12-2020

\section{ABSTRACT}

It is well-known that pulses are rich and a major source of protein in national and food composition of people of State and India. Despite the fact that pulses have many advantages, the area under the pulse crops is continuously declining over the years and area under the wheat is continuously increasing. The cost and return is also an important factor among many factors that are responsible for this decline in area under pulse crops. The data on cost of cultivation and returns were collected from Directorate of Economics \& Statistics, MoA \& FW, GOI for year 2017-18 from other research studies. It is clear that a higher variable cost is incurred on wheat crop in relation to other Pulse crops. This shows pulses are important with low inputs and can withstand in less budget situation also. Devotion of lesser and poor resources, the pulse production is also lesser and there gross return is low. The $\mathrm{B}: \mathrm{C}$ ratio ( at C 3 cost) is higher in case of wheat, while it is less than one in pulses, making the pulses less attractive for farmers in cropping pattern. Higher and ensured prices for pulses in market, higher pulse procurement at MSP, trade opportunities with opening of new venues for pulse purchase as FPOs, Agricultural based firms etc. can make the pulse production equally profitable for farmers as Wheat. With remunerative prices in pulses, the pulses will also get higher and efficient inputs, irrigated lands, the potential yield of pulses can be harnessed.

Keywords: Pulse production, Uttar Pradesh, Cost of Cultivation, Return, Wheat

Pulses are of special nutritional and economic importance due to their contribution to the diets of millions of people worldwide. The main importance of pulses lies primarily in their high protein content (two to three times higher than most cereals) with a valuable source of energy. The use of pulses as food is concentrated in developing countries accounting for about $90 \%$ of global human pulse consumption. Globally, India is the major pulses producer followed by Canada, China, Myanmar and Brazil. India is the largest producer of pulses, accounting for 25 percent of global pulses production. In a country like India, pulses are the cheapest source of dietary protein (Gautam et al. 2019). There are 17 major pulses producing States in India. The main regions with high productivity are Punjab, Haryana, Western Uttar Pradesh, West Bengal delta region, coastal Andhra Pradesh, Tamil Nadu, Kerala, coastal and eastern Karnataka and some parts of Maharashtra.

How to cite this article: Kumar, V., Meena, D.C., and Chand, K. (2020) Comparative Economics of Pulses and Wheat Production in Uttar Pradesh. Agro Economist - An International Journal, 7(2): 89-94.

Source of Support: None; Conflict of Interest: None क्ष 
Uttar Pradesh is the second largest producer of the pulse in India, both in quantity and variety. It is well known that pulses are rich and a major source of protein in national and State food composition as the majority of Indians are vegetarian. Pulses are the primary source of protein for the poor and the vegetarians who constitute the majority of the Indian population in the State and the country. While the traditional cropping pattern almost always included a pulse crop either as a mixed crop or in the rotation, the commercialization of agriculture has encouraged the practices of sole cropping. The share of Uttar Pradesh in terms of area and production of pulses in India stands at $9 \%\left(5^{\text {th }}\right)$ and $11 \%\left(4^{\text {th }}\right)$, respectively (Sharma and Sisodiya 2018). Pulses are used to serve low-cost food to get the protein requirement of a larger section of people in India. But the pulses are becoming beyond the reach for the common people of the country because of continuous increase in their prices.

\section{Cropping pattern in Uttar Pradesh}

The cropping patterns for the last ten years in Uttar
Pradesh, since 1970-71 onwards shows that the total pulses production during last fifty years had been very gloomy in Uttar Pradesh (Table 1). The area under total pulses had steadily decreased over every decade since 1970-71 onwards, and it is reduced to half, i.e. about $10 \%$ at present from about $16 \%$ in 1970-71. Among the pulse crops, a drastic reduction in the area had been found under Arhar $(2.51 \%$ to $1.30 \%)$, Pea (3.12\% to $1.19 \%$ ) and Gram (8.75 to $2.30 \%)$ over last fifty years. In contrast to these pulse crops, Lentil has gained its area from $0.72 \%$ in 1970-71 to 2.29 \% in 2010-11 (Sharma and Sisodiya 2018, Hasan and Khan 2018).

Despite the fact that pulses have many advantages, the area under the pulse crops is continuously declining over the years and area under the wheat is continuously increasing. Pulses are helpful in mitigating the climate change as needs less fertiliser production. These have broad genetic base to withstand in adverse climate. The pulses growers grow them for self consumption or for market as cash crops. The cost and return is also an important factor among many factors that are responsible for

Table 1: Cropping patterns in Uttar Pradesh since 1970-71 (Area in lakh hectares)

\begin{tabular}{llllll}
\hline \multicolumn{1}{c}{ Crops } & $\mathbf{1 9 7 0 - 7 1}$ & $\mathbf{1 9 8 0 - 8 1}$ & $\mathbf{1 9 9 0 - 9 1}$ & $\mathbf{2 0 0 0 - 0 1}$ & $\mathbf{2 0 1 0 - 1 1}$ \\
\hline Total Cereals & 67.8 & 71.66 & 67.05 & 69.62 & 69.13 \\
Rice & 19.04 & 21.53 & 22.04 & 23.34 & 22.69 \\
Wheat & 25.45 & 33.01 & 33.63 & 36.51 & 38.26 \\
Maize & 6.50 & 4.98 & 4.3 & 3.64 & 3.03 \\
Barley & 5.71 & 3.17 & 1.67 & 1.13 & 0.64 \\
Other & 11.10 & 8.97 & 5.41 & 4.99 & 4.50 \\
Total Pulses & 15.85 & 11.64 & 11.93 & 10.64 & 9.56 \\
Arhar & 2.51 & 2.13 & 1.84 & 1.61 & 1.30 \\
Pea & 3.12 & 0.91 & 1.38 & 1.32 & 1.19 \\
Lentil & 0.72 & 1.12 & 2.12 & 1.32 & 2.29 \\
Gram & 8.75 & 6.09 & 5 & 3.29 & 2.30 \\
Other & 0.75 & 1.39 & 1.59 & 3.10 & 2.48 \\
Total Oilseeds & 2.97 & 2.90 & 4.01 & 3.40 & 4.17 \\
Mustard \& rapeseed & 0.91 & 1.66 & 2.72 & 2.2 & 2.32 \\
Groundnut & 1.47 & 0.78 & 0.60 & 0.46 & 0.34 \\
Linseed & 0.29 & 0.26 & 0.37 & 0.22 & 0.11 \\
Til & 0.30 & 0.19 & 0.31 & 0.43 & 1.34 \\
Other & 0.00 & 0.01 & 0.01 & 0.10 & 0.06 \\
Potato & 0.70 & 1.08 & 1.35 & 1.56 & 2.07 \\
Sugarcane & 5.80 & 5.50 & 7.28 & 7.66 & 8.04 \\
Others & 6.88 & 7.22 & 8.38 & 7.13 & 7.04 \\
Gross cropped area & 217.30 & 232.07 & 245.74 & 253.04 & 256.15 \\
\hline Source: Sharna
\end{tabular}

Source: Sharma and Sisodiya, 2018. 
this decline in area under pulse crops. This study makes a comparative analysis of cost and returns of important pulse crops in relation to Wheat crop in Uttar Pradesh.

\section{MATERIALS AND METHODS}

The analysis of present study is based on secondary data. The data on cost of cultivation and returns were collected from Directorate of Economics \& Statistics, MoA \& FW, GOI for year 2017-18 from other research studies. The cost of cultivation and return analysis is made for important pulse crops of UP as Arhar or Red gram (Cajanus cajan), Moong or green gram (Phaseolus aureus)), Urad or Black gram (Phaseolus mungo), Gram or Chick pea (Cicer arietinum) and Lentil or Masoor (Lens eesculenta). The explanation of different cost concepts that were used is as follows:

Cost A1: All variable cost including land revenue, depreciation and Interest on working capital and excluding the family labour cost

Cost A2: Cost A1 + Rent paid for the leased land.

Cost B1: Cost A1 + Interest on value of owned capital assets (excluding Land).

Cost B2: Cost B1 + imputed rental value of owned land + Rent paid for leased land.

Cost C1: Cost B1 + Imputed value of family labour.

Cost C2: Cost B2 + Imputed value of family labour.

Cost C3: Cost C2 $+10 \%$ of cost $\mathrm{C} 2$ to account for managerial remuneration to the farmer.

Gross Return: Total value of produce (Main product and by product) multiplied by prevalent market prices

Net Return: Gross return- Total cost of cultivation

B:C Ratio: Gross Return/Total cost

\section{RESULTS AND DISCUSSION}

The cost of cultivation and returns analysis for different pulses in relation to wheat crop in Uttar Pradesh (on per hectare basis) as discussed below:

Arhar: It is found that total cost C2 (includes all variable and fixed charges) and $\mathrm{C} 3(\mathrm{C} 2+10 \%$ as risk and management charges) in production of Arhar in UP are ₹ 43301.87/ hectare and ₹ 47632.06 per hectare for year 2017-18 respectively (Table 2). For different inputs, under Cost C3, the highest expenditure is incurred on human labour $(29.20 \%)$ followed by Machine labour (8.48\%) and irrigation charges. The share of variable and fixed cost found to be $47.15 \%$ and $43.76 \%$ in total cost (C3) (Table 3). The cost of production per quintal of output is ₹ 4272.86 with C2 cost and ₹ 4700.15 with C3 cost (Table 2). The gross return is found as $₹ 46782.8$ per hectare. The net return is found as $₹ 3480.93$ per quintal with cost C2 and ₹ -849.26 with $\mathrm{C} 3$ cost. The $\mathrm{B}: \mathrm{C}$ ratio with Total cost as $\mathrm{C} 2$ is found as 1.08 and $\mathrm{B}: \mathrm{C}$ ratio with Total cost as C3 is 0.98 (Table 2).

Moong: It is found that total cost C2 (includes all Variable and fixed charges) and C3 (C2 + 10\% as risk and management charges) in production of moong in UP are ₹ 28715.89/- hectare and ₹ 31587.48 per hectare for year 2017-18 respectively (Table 2). For different inputs, under Cost C3, the highest expenditure is incurred on human labour (35.83\%) followed by Machine labour (17.99\%) and animal labour. The share of variable and fixed cost was $66.34 \%$ and $24.57 \%$, respectively in total cost (C3) (Table 3). The cost of production per quintal of output is ₹ 5452.05 with C2 cost and ₹ 5997.26 with C3 cost. The gross return is found as ₹ 25544.41 per hectare. The net return is found as $₹ 3171.48$ per quintal with cost $\mathrm{C} 2$ and $₹ 6043.07$ with $\mathrm{C} 3$ cost. The $\mathrm{B}$ : $\mathrm{C}$ ratio with total cost as $\mathrm{C} 2$ was 0.89 and $\mathrm{B}: \mathrm{C}$ ratio with total cost as C3 is 0.81 (Table 2).

Urad: The total cost C2 (includes all variable and fixed charges) and C3 (C2 $+10 \%$ as risk and management charges) in production of Urad in UP are ₹ 20670.64/- hectare and ₹ 22737.70 per hectare for year 2017-18 respectively (Table 2). For different inputs, under Cost $\mathrm{C} 3$, the highest expenditure is incurred on human labour (35.24\%) followed by Machine labour (19.14\%) and seed cost. The share of variable and fixed cost was $65.32 \%$ and $25.59 \%$ in total cost (C3) (Table 3). The cost of production per quintal of output is ₹ 5820.65 with C2 cost and ₹ 6159.45 with C 3 cost. The gross return was ₹ 13732.12 per hectare. The net return was ₹ -6938.52 per quintal with cost $C 2$ and $₹-9005.58$ with $C 3$ cost. The B:C ratio with total cost as $C 2$ was 0.66 and $B: C$ ratio with total cost as C3 is 0.60 (Table 2).

Gram: The total cost C2 (includes all variable and fixed charges) and $\mathrm{C} 3(\mathrm{C} 2+10 \%$ as risk and 
Table 2: Economics of pulses and wheat cultivation in 2017-18 (₹/ha)

\begin{tabular}{|c|c|c|c|c|c|c|}
\hline Particulars & Arhar & Moong & Urad & Gram & Lentil & Wheat \\
\hline Human Labour & 13907.91 & 11317.58 & 8012.47 & 11075.49 & 9548.36 & 12345.64 \\
\hline Animal Labour & 42.07 & 1728.96 & 319.87 & 542.75 & 0.00 & 28.27 \\
\hline Machine Labour & 4038.10 & 5681.43 & 4351.91 & 6987.88 & 5252.80 & 8603.10 \\
\hline Seed & 2053.79 & 1242.64 & 1129.16 & 5473.11 & 3641.13 & 3294.76 \\
\hline Fertilizer \& Manure & 231.18 & 64.31 & 17.29 & 713.85 & 1197.93 & 4222.46 \\
\hline Insecticides & 293.27 & 502.08 & 596.71 & 571.30 & 62.61 & 112.92 \\
\hline Irrigation Charges & 1305.08 & 0.00 & 59.77 & 2227.29 & 2212.50 & 7820.03 \\
\hline Payment to Contractor & 190.14 & 0.00 & 0.00 & 0.00 & 0.00 & 0.00 \\
\hline Miscellaneous & 0.00 & 18.84 & 69.48 & 12.99 & 3.88 & 0.22 \\
\hline Interest on Working Capital & 395.49 & 398.21 & 295.89 & 649.78 & 495.19 & 912.85 \\
\hline Variable cost & 22457.03 & 20954.05 & 14852.55 & 28254.44 & 22414.40 & 37340.25 \\
\hline Fixed Costs & 20844.84 & 7761.84 & 5818.09 & 16423.46 & 15529.69 & 25130.91 \\
\hline Rental Value of Owned Land & 15485.48 & 6432.92 & 4434.71 & 10534.52 & 10391.67 & 17793.78 \\
\hline Rent paid for leased in Land & 0.00 & 0.00 & 0.00 & 0.00 & 0.00 & 591.10 \\
\hline Land Revenue, Taxes, Cesses & 16.61 & 8.63 & 6.37 & 9.32 & 10.53 & 3.63 \\
\hline \multicolumn{7}{|l|}{ Building } \\
\hline Interest on Fixed Capital & 4008.23 & 966.69 & 1184.43 & 5031.12 & 4287.29 & 5626.71 \\
\hline Total Cost (C2) & 43301.87 & 28715.89 & 20670.64 & 44677.90 & 37944.09 & 62471.16 \\
\hline Total cost (C3) & 47632.06 & 31587.48 & 22737.70 & 49145.69 & 41738.50 & 63368.06 \\
\hline Yield (q/ha) & 8.44 & 4.84 & 3.35 & 8.43 & 7.47 & 35.12 \\
\hline Cost of production $(₹ / q)$ at $C 2$ & 4272.86 & 5452.05 & 5820.65 & 5086.37 & 5076.18 & 1485.05 \\
\hline Cost of production $(₹ / q)$ at $C 3$ & 4700.15 & 5997.26 & 6159.45 & 5595.01 & 5583.80 & 1633.56 \\
\hline \multicolumn{7}{|l|}{ Returns } \\
\hline Gross return (₹/ha) & 46782.80 & 25544.41 & 13732.12 & 34319.88 & 31486.68 & 70442.9 \\
\hline Net Return (₹/ha) on C2 & 3480.93 & -3171.48 & -6938.52 & -10358.02 & -6457.41 & 7971.74 \\
\hline Net Return (₹/ha) on C3 & -849.26 & -6043.07 & -9005.58 & -14825.81 & -10251.82 & 7074.84 \\
\hline $\mathrm{B}: \mathrm{C}$ Ratio with $\mathrm{C} 2$ as total cost & 1.08 & 0.89 & 0.66 & 0.77 & 0.83 & 1.13 \\
\hline B:C Ratio with C3 as total cost & 0.98 & 0.81 & 0.60 & 0.70 & 0.75 & 1.11 \\
\hline
\end{tabular}

Source: Directorate of Economics and Statistics, MoA\&FW, GOI for year 2017-18.

management charges) in production of Gram in UP are $₹ 44677.90 /$ - hectare and $₹ 49145.69$ per hectare for year 2017-18, respectively (Table 2). For different inputs under Cost $\mathrm{C} 3$, the highest expenditure is incurred on human labour $(22.54 \%)$ followed by Machine labour $(14.22 \%)$ and seed cost. The share of variable and fixed cost was $57.49 \%$ and $33.42 \%$ in total cost (C3) (Table 3). The cost of production per quintal of output was ₹ 5086.37 with C2 cost and ₹ 5595.01 with C3 cost. The gross return was ₹ 34319.88 per hectare. The net return was $₹-830.55$ per quintal with cost $C 2$ and $₹-7205.91$ with $C 3$ cost. The $\mathrm{B}: \mathrm{C}$ ratio with total cost as $\mathrm{C} 2$ is 0.77 and $\mathrm{B}: \mathrm{C}$ ratio with total cost as $\mathrm{C} 3$ is 0.70 (Table 2).

Lentil: The total cost $\mathrm{C} 2$ (includes all variable and fixed charges) and C3 (C2 $+10 \%$ as risk and management charges) in production of Lentil in UP are ₹37944.09/- hectare and ₹ 41738.50 per hectare for the year 2017-18, respectively (Table 2). For different inputs under Cost C3, the highest expenditure is incurred on human labour (22.88\%), followed by Machine labour (12.59\%) and seed cost. The share of variable and fixed cost is found as $53.70 \%$ and $37.21 \%$ in total cost (C3) (Table 3). The cost of production per quintal of output is ₹ 5076.18 with C2 cost and $₹ 5583.80$ with C 3 cost. The gross return is $₹ 31486.68$ per hectare. The net return is ₹ -6457.41 per quintal with cost $C 2$ and ₹ -10251.82 with $C 3$ cost. The B:C ratio with total cost as $\mathrm{C} 2$ is 0.83 and $\mathrm{B}$ : $\mathrm{C}$ ratio with total cost as C3 is 0.75 (Table 2). 
Table 3: Input-wise cost as percentage to total cost of pulses and wheat cultivation

\begin{tabular}{lllllll}
\hline Particulars & Arhar & Moong & Urad & Gram & Lentil & Wheat \\
\hline Human Labour & 29.20 & 35.83 & 35.24 & 22.54 & 22.88 & 19.48 \\
Animal Labour & 0.09 & 5.47 & 1.41 & 1.10 & 0.00 & 0.04 \\
Machine Labour & 8.48 & 17.99 & 19.14 & 14.22 & 12.59 & 13.58 \\
Seed & 4.31 & 3.93 & 4.97 & 11.14 & 8.72 & 5.20 \\
Fertilizer \& Manure & 0.49 & 0.20 & 0.08 & 1.45 & 2.87 & 6.66 \\
Insecticides & 0.62 & 1.59 & 2.62 & 1.16 & 0.15 & 0.18 \\
Irrigation Charges & 2.74 & 0.00 & 0.26 & 4.53 & 5.30 & 12.34 \\
Payment to Contractor & 0.40 & 0.00 & 0.00 & 0.00 & 0.00 & 0.00 \\
Miscellaneous & 0.0 & 0.06 & 0.31 & 0.03 & 0.01 & 0.00 \\
Interest on Working Capital & 0.83 & 1.26 & 1.30 & 1.32 & 1.19 & 1.44 \\
Variable cost & 47.15 & 66.34 & 65.32 & 57.49 & 53.70 & 58.93 \\
Fixed Costs & 43.76 & 24.57 & 25.59 & 33.42 & 37.21 & 39.66 \\
Rental Value of Owned Land & 32.51 & 20.37 & 19.50 & 21.44 & 24.90 & 28.08 \\
Rent paid for leased in Land & 0.00 & 0.00 & 0.00 & 0.00 & 0.00 & 0.93 \\
Land Revenue, Taxes, Cesses & 0.03 & 0.03 & 0.03 & 0.02 & 0.03 & 0.01 \\
Depreciation on Implements \& Farm Building & 2.80 & 1.12 & 0.85 & 1.73 & 2.01 & 1.76 \\
Interest on Fixed Capital & 8.41 & 3.06 & 5.21 & 10.24 & 10.27 & 8.88 \\
Total Cost (C2) & 90.91 & 90.91 & 90.91 & 90.91 & 90.91 & 98.58 \\
Total cost (C3) & 100.00 & 100.00 & 100.00 & 100.00 & 100.00 & 100.00 \\
\hline
\end{tabular}

Source: Directorate of Economics and Statistics, MoA\&FW, GOI for year 2017-18.

Wheat: The total cost $\mathrm{C} 2$ (includes all variable and fixed charges) and $\mathrm{C} 3(\mathrm{C} 2+10 \%$ as risk and management charges) in production of Wheat in UP are ₹ 62471.16/- hectare and ₹ 63368.06 per hectare for year 2017-18, respectively (Table 2). For different inputs under Cost $\mathrm{C} 3$, the highest expenditure is incurred on human labour $(19.48 \%)$, followed by machine labour $(13.58 \%)$ and irrigation charges. The share of variable and fixed cost is $58.93 \%$ and $39.66 \%$ in total cost (C3) (Table 3). The cost of production per quintal of output is ₹ 1485.05 with C2 cost and ₹ 1633.56 with C3 cost. The gross return is ₹ 70442.9 per hectare. The net return is ₹ 7971.74 per quintal with cost $\mathrm{C} 2$ and $₹ 7074.84$ with $\mathrm{C} 3$ cost. The $\mathrm{B}$ : $\mathrm{C}$ ratio with total cost as $\mathrm{C} 2$ is 1.13 and $\mathrm{B}: \mathrm{C}$ ratio with total cost as C3 is 1.11 (Table 2).

The variable cost of cultivating wheat is higher compared to pulses. The variable cost incurred on wheat is ₹ 37340.25 per hectare, while that in Arhar, Moong, Urad, Gram, Lentil is ₹ 22457.03, ₹ 20954.05, ₹ 14852.55 , ₹ 28254.44 , ₹ 22414.40 per hectare, respectively. This shows that pulses are important with low inputs and can withstand in less budget situation also (Kumar, 2012). Thus, pulses reduce the production risk of farmers. The rental value of land for wheat is also higher in relation to that of pulses. It shows that wheat crop is given better land equipped with irrigation, while in case of pulses; the rental is very low which is mainly grown in rainfed lands. This also shows that pulses have higher capacity to grow on all types of land. Due to the less investment in cultivation of pulses, their productivity is also lesser and therefore the gross return is also low. The net return is negative except for Arhar. The net return (at C3 cost) is ₹ 7074.84 per hectare in wheat, but it is quite low and negative for all pulse crops. The $\mathrm{B}: \mathrm{C}$ ratio (at $\mathrm{C} 3$ cost ) is more than one in case of wheat, while it is less than one in pulses, making the pulses less attractive for farmers in cropping pattern (Table 2).

\section{CONCLUSION}

The pulses have many production advantages compared to wheat or other cereals. Pulses enrich soil with nitrogen thus suitable for sustainable production and organic farming for inter cultivation. These provide the protein to people and with stand in low budget situation. Government policies as National Food Security Mission (NFSM) on pulses and favourable climate have increased the pulses 
production in India (Varma 2019) Higher and ensured prices for pulses in market, trade opportunities with opening of new venues for pulse purchase as FPOs, agricultural based firms etc. can make the pulse production equally profitable for farmers as wheat (Singh et al. 2017). The MSP alone will not be suitable for enhancement of pulse production, the procurement of Pulse at MSP should also be enhanced which is 1-4 \% of total pulse production (Varma 2019). Thus, there should be other avenues for pulses procurement at remunerative prices. With remunerative prices in pulses, the pulses will also get higher and efficient inputs, irrigated lands, the potential yield of pulses can be harnessed.

\section{REFERENCES}

Gautam, U.S., Singh, Atar, Dubey, S.K., Pandey, Sadhna, Yemul, S.N. Singh, Rajeev, Singh, M.K. 2019. Performance of Pulse demonstrations in Uttar Pradesh Application of Technology by KVKs under NFSM (2017-18). ICAR-ATARI, Zone-III, Kanpur, Pp. 25.

Hasan, R. and Khan, D.N. 2018. Diagnosis of pulse production and consumption in Uttar Pradesh: an inter-regional analysis. International Journal of Current Microbiology and Applied Sciences, 7(07): 860-865.
Kumar, S. 2012. Economic analysis of pulses production their benefits and constraints (a case study of sample villages of Assam valley of Uttarakhand, India). IOSR Journal of Humanities and Social Science, 1(4): 41-53.

Sharma, M.K. and Sisodiya, B.V.S. 2018. Pulses are out of reach: A regional study of Uttar Pradesh. International Journal of Agriculture Sciences, 10(5): 5335-5342.

Singh, P., Shahi, B. and Singh, K.M. 2017. Trends of pulses production: a study on current scenario and strategies in India with special reference to Bihar. Economic Affairs, 62(3): 389-398.

Varma, P. 2019. Production, markets and trade: A detailed analysis of factors affecting pulse production in India. Final report. Centre of management in Agriculture, IIM (Ahemdabad), March 2019.

GoI. 2020. Agricultural Statistics at a Glance (2004 to 2019). Directorate of Economics and Statistics, Department of Agriculture, Cooperation and Farmers Welfare, Ministry of Agriculture and Farmers Welfare. 